\title{
Coeliac disease in monozygotic twins
}

\author{
DENNIS J. SHALE* \\ M.D., M.R.C.P. \\ DESMOND G. JOHNSTON† \\ M.R.C.P. \\ REGINALD HALL** \\ M.D., F.R.C.P. \\ D. F. ROBERTS $\ddagger$ \\ Sc.D. \\ ${ }^{*}$ Osler Chest Unit, Churchill Hospital, Oxford OX3 $7 L J$, $\nmid$ Royal Victoria Infirmary, \\ Newcastle upon Tyne NEI 4LP, \\ **Welsh National School of Medicine, Cardiff and $\ddagger$ University of Newcastle upon Tyne, \\ Newcastle upon Tyne
}

\begin{abstract}
Summary
A case of concordance for coeliac disease in monozygous twins is reported. One presented with failure to enter puberty and responded to the exclusion of gluten from her diet. The other twin was asymptomatic. They represent a well documented example of monozygous twins with concordance for coeliac disease.

\section{Introduction}

Coeliac disease has a high familial incidence (McCrae, 1969; Walker-Smith, 1973; McNeish and Anderson, 1974; David and Ajdukiewicz, 1975) and the mode of inheritance of susceptibility has been considered to be multifactorial (Robinson et al., 1971). Studies in twins provide an opportunity to explore the relative importance of heredity and environment in the aetiology of the disease. Thus in monozygous twins concordance is evidence for and discordance evidence against a major genetic role.

Six pairs of twins with discordance for coeliac disease have been reported (Carter, Sheldon and Walker, 1959; Hoffman, Wollaeger and Greenberg, 1966; Walker-Smith, 1973; Polanco et al., 1981), although the criteria for monozygosity in some of the earlier reports are necessarily lax by present standards. However, two sets of twins reported had a high probability of monozygosity (Polanco et al., 1981). Many cases of concordant coeliac disease in monozygous twins have been reported (Polanco et al., 1981), but again the criteria of monozygosity can be questioned in many. There are only two well documented sets of monozygous twins concordant for coeliac disease (Penna et al., 1979; Polanco et al., 1981).

We report a case of concordance for coeliac disease in twins with a high probability of monozygosity causing growth failure in one twin.
\end{abstract}

\section{Case reports}

\section{Twin 1}

E.M., female aged 14 years, birth weight $2.98 \mathrm{~kg}$, was the larger twin until three years before presentation. Two years before presentation the patient had intermittent anorexia and vomiting, for 12 months, associated with weight loss of $3 \mathrm{~kg}$. There was no history to suggest coeliac disease in the family. She presented with delayed puberty and was noted to be smaller than her twin. Investigations showed a hypochromic anaemia (haemoglobin $(\mathrm{Hb}) 9.7 \mathrm{~g} / \mathrm{dl}$ ) with a low serum iron and elevated transferrin. Serum and red cell folate and vitamin B 12 levels were normal. Serum calcium concentration was low $(2.05 \mathrm{mmol} /$ litre) with normal serum proteins, alkaline phosphatase and plasma inorganic phosphate. Faecal fat excretion was elevated at $25 \cdot 1 \mathrm{mmol} / 24 \mathrm{hr}$ (normal $18 \mathrm{mmol} / 24 \mathrm{hr}$ ). Her radiological bone age was 12 years. Duodenal biopsy showed villous atrophy on stereomicroscopy, and histology confirmed a flat mucosa with crypt hyperplasia and a great excess of plasma cells and lymphocytes in the lamina propria. Treatment with a gluten free diet resulted in a marked gain in weight and height. After 43 weeks the patient had entered puberty (breast development stage 3, pubic hair stage 2 (Tanner, 1962)) but had not menstruated. Repeat duodenal biopsy, 34 weeks after gluten withdrawal, revealed villi on stereomicroscopy, confirmed on histology, although a slight excess of inflammatory cells was noted in the lamina propria.

\section{Twin 2}

M.M., female aged 14 years, birth weight $2.59 \mathrm{~kg}$. She had no spontaneous complaints. Menarche had occurred at 12.5 years with irregular menses follow- 
ing this. She was normal on examination and well into puberty (breasts stage 4 , pubic hair stage 4 (Tanner, 1962)). The only abnormality found on investigation was a hypochromic anaemia $(\mathrm{Hb} 10.8$ $\mathrm{g} / \mathrm{dl}$ ) and jejunal biopsy showed total villous atrophy with cellular infiltration. The patient was placed on a gluten free diet.

Examination of a series of monogenic characters showed no discordance between the twins. From the findings at the 25 loci (Table 1), the probability is 0.99927 that the twins are to be regarded as monozygous.

TABLE 1. Results of blood tests for genetic markers in both twins

\begin{tabular}{|c|c|c|c|}
\hline \multicolumn{2}{|l|}{$A B O$ System } & \multicolumn{2}{|l|}{ Red cell enzymes } \\
\hline $\mathrm{ABO}$ & 0 & Lactate dehydrogenase & $\mathrm{N}$ \\
\hline MNSs & MsNs & Malate dehydrogenase & $\mathbf{N}$ \\
\hline Rhesus & $\mathrm{CcDEe}$ & Adenylate kinase & $1-1$ \\
\hline Kell & kk & Adenosine deaminase & $1-1$ \\
\hline Duffy & $\mathrm{Fy}^{\mathrm{a}+\mathrm{b}+}$ & Phosphoglucomutase $_{1}$ & $1-1$ \\
\hline Kidd & $\mathrm{Jk}^{\mathrm{a}-\mathrm{b}+}$ & Phosphoglucomutase & $1-1$ \\
\hline Lutheran & $\mathrm{Lu}^{\mathrm{a}-\mathrm{b}+}$ & Acid phosphatase & BA \\
\hline $\mathrm{Xg}$ & $\mathrm{Xg}^{\mathrm{a}-}$ & Esterase-D & $1-1$ \\
\hline Serum proteins & & $H L A$ & \\
\hline Transferrin & Tf C & HLA Al & \\
\hline Complement $\mathrm{C}_{3}$ & SS & A29 & \\
\hline Haptoglobin & $2-1$ & B8 & \\
\hline $\mathrm{Bf}$ & SF & BW45 & \\
\hline
\end{tabular}

\section{Discussion}

A major problem with twin studies in coeliac disease has been the difficulty of establishing monozygosity to a high degree of probability. This was particularly so in earlier reports and as late as the report of Penna et al. (1979) monozygosity was based on a shared placenta, physical similarities, dermatoglyphics and shared blood group characteristics. A better probability of monozygosity can now be given based on a wider analysis of antigenic and biochemical genetic markers as performed in the case of the twins presented here. Thus the twins reported here together with the case reported by Polanco et al. (1981) represent the best documented examples of concordance for coeliac disease in monozygous twins.

Growth and development were normal in one twin, emphasizing the importance of intestinal biopsy before discordance or concordance is established. Further twin studies in coeliacs will provide cumulative information on the inheritance of this condition and the interaction of environmental factors with inheritance.

\section{References}

Carter, C.. Sheldon, W. \& Walker, C. (1959) The inheritance of coeliac disease. Annals of Human Genetics, 23, 266.

DAVID, T.J. \& AJdUKIEWICZ, A.B. (1975) A family study of coeliac disease. Journal of Medical Genetics, 12, 79.

Hoffman, H.N., Wollaeger. E.E. \& GreenberG, E. (1966) Discordance for non-tropical sprue (adult coeliac disease) in a monozygotic twin pair. Gastroenterology, 51, 36.

MCCRAE, W.M. (1969) Inheritance of coeliac disease. Journal of Medical Genetics, 6, 129.

MCNeish, A.S. \& Anderson, C.M. (1974) Coeliac disease. The disorder in childhood. Clinics in Gastroenterology, 3, 127.

Penna, F.J., Mota, J.A.C., RoQuete, M.L.V., Carvalho, A.S.T., Lemos, A.T.O., Barbosa, A.J.A., Leao, E., Ferreira, R.A. \& CASTRO, L.P. (1979) Coeliac disease in identical twins. Archives of Disease in Childhood, 54, 395.

Polanco, I., Biemond, I., Van leeuwen, A., Schreuder, I., Meera Khan, P., Guerrero, J., D'Amaro, J., Vazquez, C., VAN ROOD, J.J. \& PEṄA, A.S. (1981) Gluten sensitive enteropathy in Spain: genetic and environmental factors. In: The Genetics of Coeliac Disease (Ed. by McConnell, R.B.), p. 211. MTP press, Lancaster.

Robinson, D.G., Watson, A.J., Wyatt, E.H., MaRks, J.M. \& ROBERTS, D.F. (197I) Incidence of small-intestinal mucosal abnormalities and of clinical coeliac disease in the relatives of children with coeliac disease. Gut, 12, 789.

TANNER, J.M. (1962) The development of the reproductive system In: Growth at Adolescence. Chapter 2. Blackwell Scientific, Oxford.

WALKER-SMITH, J.A. (1973) Discordance for childhood coeliac disease in monozygotic twins. Gut, 14, 374. 